\title{
Uit genade alleen? Herbesinning oor die Romeinebrief deur Suid-Afrikaanse teoloë
}

\author{
H A Lombard \\ Universiteit van Suid-Afrika
}

\begin{abstract}
Through faith, from beginning to end? Rethinking the Letter to the Romans by South African theologians
\end{abstract}

As material for and reflection on religious issues by Christians, the letter to the Romans used to be a document of fundamental importance. It ought to be applauded that in 1989 a contribution to this letter was made by South Africans in their own context, with a view to meeting their situation and needs. The eleven contributions represent the authors' religious sense of responsbility and social sensitivity. They also display the nature and content of their hermeneutical vantare points and their competence in exegetical procedures. Apart from the merit and indisputable value of these contributions, cognizance should also be taken of deficiencies with regard to methodological precision and competence in some of the articles. A salient deficiency is the lack of cognizance of the work of South African theologians and discussions with them. This is to be regretted.

\section{INLEIDENDE OPMERKINGS: DIE SCENARIO}

In 1989 het die twaalfde in 'n reeks van jaarlikse publikasies (sedert 1978) van die Instituut vir Teologiese Navorsing aan die Universiteit van Suid-Afrika verskyn. Hierdie boek, getiteld Uit genade alleen?, wat onder redaksie van W S Vorster \& A $S$ Engelbrecht uitgegee is, is van stapel gestuur deur die C B Powell Bybelsentrum wat deel vorm van die Instituut en bevat 'n versameling van elf lesings wat in 1988 by die Bybelsentrum oor die Romeinebrief gelewer is. 
Om hierdie 'hoofbrief' van Paulus as seminaar-onderwerp te kies, was beslis 'n aanprysenswaardige stap waarmee die destydse hoof van die Bybelsentrum, prof PGR de Villiers, gekomplimenteer moet word. Immers, die Romeinebrief vorm ' $n$ baie belangrike deel van die Pauliniese teologie en van diverse teologiese temas in die Nuwe Testament; in die geskiedenis van navorsing en in dogmenhistoriese perspektief staan dit ook hoog op die prioriteitslys, terwyl dit nog altyd 'n belangrike bron in gesprekke en kontroverse rondom temas soos soteriologie (kyk Rom 1:1617; 2:3v; 5:1-11, et al), uitverkiesing (kyk Rom 9-11), kerk-staat verhoudings (kyk Rom 13), Christelike etiek (kyk Rom 12vv), ensovoorts was.

In die lig van hierdie verwysingsraamwerk met betrekking tot die belangrikheid en aktualiteit van die Romeinebrief dring hierdie versameling lesings deur tot die kern van teologiese besinning wat relevant is vir algemene Bybelondersoek, maar ook vir die besondere konteks in Suid-Afrika.

Ten opsigte van laasgenoemde konteks is dit ook belangrik om te konstateer dat hierdie lesings tot 'n hoë mate aanleiding gevind het en aangepak is in 'n SuidAfrikaanse Sitz im Leben. Bybelse perspektiewe oor konkrete sake, teologies, maar ook godsdienstig, sosio-polities en andersins word na vore gebring. Hierdie omvattende konteks van die teoloè vorm - soos dit altyd die geval is - deel van hulle paradigmas van verstaan en vertrekpunte in hulle pogings om die Romeinebrief uit te lê.

Die teoloë wat hierdie bydraes gelewer het, geniet redelike tot hoë aansien in akademiese kringe. Die dissiplines waarin hulle spesialiseer, is Kerkgeskiedenis (een persoon), Nuwe-Testamentiese Wetenskap (vier persone), Ou-Testamentiese Wetenskap (een persoon), Ou-Testamentiese Wetenskap en Kerkgeskiedenis (een persoon), Praktiese Teologie en Sistematiese Teologie (een persoon) en Sistematiese Teologie (twee persone).

\section{INDIVIDUELE BYDRAES: WAARDERING EN KRITIEK}

Heel gepas het $C J$ Botha in die eerste artikel 'n waardevolle oorsig gegee van tradisionele inleidingsvrae oor die Romeinebrief en sy rol in die loop van die kerkgeskiedenis. Hy redeneer dat hierdie rol reeds in die Nuwe Testament self na vore kom in die invloed van die Romeinebrief op 1 Petrus, Hebreërs en Jakobus en dan in die vroeg-Christelike literatuur vanaf Klemens van Rome (93-97 $n \mathrm{C}$ ) en verder by die Apologete (derde tot vyfde eeue), Middeleeuse skolastici, Reformatore (sestiende eeu) tot by Karl Barth in sy epogmakende geskrif, Die Römerbrief, direk na die katastrofe en skokkende ontnugtering van die Eerste Wêreldoorlog. Hierdie oorsig is 'n knap stuk werk van Botha as kerkhistorikus waarin hy 'n goeie analise 
van primêre en sekondêre literatuur gemaak het.

Dit is egter ' $n$ groot tekortkoming in Botha se benadering en in sy aanbieding dat hy die voortgaande belangrike rol van die Romeinebrief nie vanaf Barth deurgetrek het na die moderne besinning wat ná die Tweede Wêreldoorlog en tot in die hede plaasgevind het nie - sy nuutste bron dateer uit 1971! Hy maak ongelukkig ook gén melding van die rol wat die Romeinebrief in Suid-Afrikaanse teologieë en in die Suid-Afrikaanse kerkgeskiedenis gespeel het nie. En dít terwyl die opset van die oorspronklike lesings en hierdie publikasie juis was en is om met 'n kritiese ingesteldheid opnuut in 1988 na die betekenis en rol van die Romeinebrief in die Suid-Afrikaanse situasie te kyk. Die teologieë en kerke in Suid-Afrika is 66́k, ja selfs ' $n$ belangrike, deel van die besinning binne en geskiedenis van die Christendom. Dit sou dan ook beter gewees het, en 'n vollediger beeld geskep het, as Botha saam met Kenneth Scott Latourette (1954) verwys het na die 'Geskiedenis van die Christendom' in plaas van 'Kerkgeskiedenis', en hierdie volle spektrum in sy oorsig gedek het.

As Nuwe-Testamentikus het $A B$ du Toit op klassieke wyse na die 'sleutel' tot die Romeinebrief (1:16-17) gekyk. Die kritiek (verwyt!) dat hierdie benadering agterhaald is, word ondervang deurdat sy analise, sintese en toepassing verder ook nog vanuit die perspektief van die retoriese situasie van Romeine (bl 17v) benader is. Met behulp van 'n literêr-kritiese paradigma van verstaan van die Romeinebrief vra hy die belangrike vraag binne welke situasie die outeur sy lesers wou oortuig van belangrike veranderinge van persepsie en lewenswyse wat hulle moes ondergaan. Du Toit wys egter ook tereg daarop dat die oorredingsmotief, soos geïdentifiseer deur en vanuit die perspektief van taalhandelinge en lesersrespons, nie die enigste kyk op die Romeinebrief bied nie en dat hierdie motief waarskynlik ook nie die enigste en finale rede vir die skrywe van die brief is nie.

Die bydrae wat $\mathrm{Du}$ Toit lewer, is 'n baie waardevolle een waarin die betekenis van die Romeinebrief kragtens die aspek van die pragmatiek van hierdie teks as literêre teks, na ons eie tyd se mense deurgetrek word. Verder word ook enkele bydraes van Suid-Afrikaanse teoloë deur verwysing en bespreking tot hulle reg laat kom.

Dit is baie gepas om 'n Ou-Testamentikus, $W J$ Wessels, oor Habakuk te laat skrywe om hierdie Ou-Testamentiese profeet wat figureer in Romeine 1:17, Galasiërs 3:11 en Hebreërs 10:37v, beter te verstaan. Na gelang van die mate wat 'n verantwoorde verstaansmodel vir die verhouding die Ou Testament tot die Nuwe Testament funksioneer, is Wessels se toespitsing op die uitleg van Habakuk 2:4 in sy 
omvattende konteks en sleutelposisie in die hele profesie gewis bevorderlik vir die verstaan van Romeine 1:17. Sy beklemtoning van die sentrale gedagte van hierdie profesie, veral Habakuk 2:4 in konteks, is as verstaansmodel en werkhipotese hier van besondere belang. Saam met Boadt (1982:181) konstateer hy op grond van Habakuk se profesie dat God nie politieke of interne sukses vir die mens beoog nie en dat $\mathrm{Hy}$ ook nie optree om alleenlik maar politieke of onmiddellike voordele (vir mense) te verskaf nie. Nee, God vra vir 'fidelity in patience'. In ruil hiervoor gee Hy die lewe vir diegene wat geduldig wag en getrou op God se beloftes reken.

GM M Pelser (bl 29-54) ontsluit op 'n metodologies aanvaarbare en duidelike wyse vir die leser 'n moeilike gedeelte van die Romeinebrief, naamlik 1:18-3:20. Die groot vrae rondom die kernsake soos regverdigmaking en verlossing van die Jood en nie-Jood word uit die kern van die Romeinebrief en ook die hele evangelie beantwoord. Alle mense (Jode en nie-Jode) is doemwaardig voor God en is dus vir verlossing op God se genade en voorsiening aangewese. Pelser fokus die soeklig skerp op die titel en tema van die publikasie, naamlik Uit genade alleen?, wat uit hierdie gedeelte van die brief kom. Die vraagteken agter die titel word dan eintlik deur sy perspektiewe in 'n uitroepteken verander en ook die moderne gelowige, die niegelowige en die skyn-gelowige ( $\mathrm{d}$ i die godsdienstige ongelowige!) word voor hierdie appél geplaas (bl 51).

Die uitgebreide literatuurlys van vyf-en-veertig titels is uiters waardevol vir enige student van die Romeinebrief. Dit verskaf voorbeelde van die formulering en toepassing van die belangrikste paradigmas vir die verstaan en interpretasie van die Romeinebrief vanaf 1914 tot en met 1986.

Dit is egter jammer dat Pelser nêrens deur enige verwysing na bronne 'n aanduiding gee waar en hoe hy met geleerdes in gesprek tree nie. Dit laat, om die minste te sê, die vraag ontstaan of hierdie literatuurlys die aantal geraadpleegde werke aangee, en of dit vir eie leeswerk en verdere studie van die lesers bedoel is? Indien dit die bronne vir die formulering van die eindresultate van die artikel verteenwoordig, word onmiddellik gesoek na 'n bekendstelling en verduideliking van die suksesformule wat toegepas is om soveel uiteenlopende paradigmas en standpunte op so 'n harmonieuse wyse met mekaar te korreleer en te integreer.

$J$ H le Roux (bl 55-63) teken in duidelike terme die aard en krag van die geloof van Abraham - die man wat as 'n soort (arge)tipe van gelowigheid in Romeine 4 en Hebreërs figureer. Vir hierdie literêre skildery word Genesis 12-25 onder die loep van ' $n$ analitiese Bybelkundige geplaas. Aan die einde van sy lewe het Abraham van God se beloftes van 'n groot nageslag en 'n land slegs een kind en 'n stukkie 
grafgrond gehad! Maar ten spyte hiervan staan Abraham se volharding in die geloof dat God sal voorsien en sy hoop in wanhopige situasies en gebeure steeds voorop.

Met sy vertelling oor en parafrase van Abraham se geskiedenis slaag Le Roux op kenmerkende wyse daarin om Godsvertroue as kernaspek van geloof uit te lig. Dus, in plaas van 'n gedokumenteerde akademiese referaat is hierdie bydrae die improvisasie van 'n vakkundige Ou-Testamentikus wat put uit 'n korrelasie van sy wetenskaplike vermoë èn sy religieuse sensitiwiteit en ervaring.

$W A$ Sebothoma (bl 64-74) voeg hom as Nuwe-Testamentikus by Le Roux in sy besinning oor Abraham se geloof as model van die Christelike geloof. Sy vergelykingsmodelle word beskryf uit inligting verkry uit Genesis 12vv en Romeine 3:215:2. In sy analises van die twee komponente uit die Bybel maak hy gebruik van goed verantwoorde hermeneutiese beginsels, naamlik onder andere om Genesis in die konteks van segswyses en die denkwêrelde van die Ou Testament, Oud-Israel en Judaïsme te interpreteer, en die Romeinebrief in dié van die eerste-eeuse Christendom-in-ontwaking.

Sebothoma kom tereg tot die belangrike slotsom dat vir beide Abraham en Paulus geloof nie abstrak is nie, maar eksistensieel. Hierdie geloof gedy in 'n gelowige gemeenskap van eenheid en waar daar ook 'n eskatologiese gerigtheid is. Godsdienstigheid beteken vir beide figure godsdienstige gehoorsaamheid (bl 68). Deur hierdie sieninge raak te sien en eksegeties binne sy paradigma te substansieer, slaag Sebothoma daarin om historiese en teologiese konteks van Ou- en NuweTestamentiese perspektiewe in, onder andere, die gebeure van herkontekstualisering te korreleer. Die waarde van sy bydrae tot hierdie bundel en tot besinning oor die Romeinebrief is dat hy geloof kwalifiseer as 'n weg tot ware lewe, èn 'n weg/wyse van volkome lewe.

Binne die perke en terme van sy verstaansmodel en prosedure van interpretasie van die Bybel, het Sebothoma op duidelike en konsistente wyse sy analise gemaak en sy beskouing gelegitimeer.

Die vraag ontstaan egter of hy al die inligting wat in sy artikel vervat en verwerk is, sy eie breinvrug is. Geen verwysing na bronne en ook geen literatuurverwysingslys is by sy bydrae gevoeg nie.

In sy studie van Romeine 6-8 gee $J G$ Swanepoel 'n uitleg van die betekenis van teologiese temas wat hier voorkom, soos doop, opstanding, vryspraak, diensbaarheid van sonde en van God (respektiewelik van die wet en die Gees). Die outeur verstrek hierin sy manier van verstaan, uitleg en interpretasie van hierdie drie hoofstukke van die Romeinebrief. Hy bied dit aan as 'n soort finale eksegese van 
die gedeeltes. Om tot hierdie byna dogmatistiese opvatting oor die Romeinebrief te kom, volg hy 'n eksegetiese prosedure wat 'n vermenging van die grammaties-historiese, strukturalistiese, histories-kritiese (veral redaksiehistoriese), selfs iets van literêr-kritiese (veral retoriese kritiek) en ook nog tekskritiese benaderings. Hierby word Skrif-analogieë en parafrasering ook veelvuldig as modelle vir uitleg toegepas.

Op die oog af lyk dit asof die leser die artikel soos 'soet koek' kan verorber, veral as hy/sy daarop ingestel is om inligting oor Paulus se teologiese gedagtes an sich te verkry. Die aanname en suggestie van so 'n aanbieding by Swanepoel is dat hy Paulus homself laat interpreteer; by die leser is die aanname by so ' $n$ behoefte dat dit so maklik is om Paulus homself te laat interpreteer!

Sulke aannames en suggesties is ' $n$ groot vergissing aan beide kante. Die fout hier is dat die teoloog nie behoort te maak, soos Swanepoel, om reeds in die proses van sy analises met apodiktiese uitsprake in die vorm van sinteses na vore te kom nie. 'n Goeie voorbeeld hiervan is op bladsy 76-78 waar hy sy opvattings en konklusies oor die doop in Romeine 6 inlees into the mind of Paul.

'n Ander voorbeeld is sy verstaan en uitleg van Romeine 7:7-25 (kyk bl 83-87). Hy gee 'n opsomming van verskeie teoloë se standpunte oor hierdie moeilike gedeelte (bl 84). Die ses interpretasies van teoloë word egter nie op 'n sistematiese wyse krities bespreek nie. Hy wys dit af dat die 'ek' in 7:1 slaan op die mens v66r die sondeval (opvatting 3), om dan sonder meer oor te gaan na 'n bepaling van die betekenis van die frase 'voor die wet'. Volgens hom slaan dit ook nie op die tyd voor die val nie, maar slegs op een van twee situasies, naamlik, die tydperk voor die Sinaï-wetgewing, of die tyd in Paulus se eie lewe toe die wet nog nie 'n houvas op hom gehad het nie. Respektiewelik slaan die 'ek' dan op Israel voor Sinaï, of op 'n outobiografiese aanduiding van die mens synde in dieselfde posisie as Paulus. Laasgenoemde beskryf dan twee lewensfases in verhouding tot die wet, te wete lewensbeskerming (voor bar-mitzwah) en wetsblootstelling (daarna). In die lig van Romeine 7:7-8 wys hy die eerste uitleg af, want hy sien dit so dat dit hier gaan om die 'kontras en spanning wat in die mens se eie bestaan ervaar word (kyk bl 85). Hiervolgens sou Paulus die ellendigheid van die mens onder die wet in kontras met die lewe onder die genade teken en daarmee die wet versus die genade teken.

Volgens Swanepoel skets Paulus in Romeine 7:13-23 dan verder die skrikwekkende implikasies van fase 2 van die mens se lewe waarin twee impulse op die ten volle toerekenbare mens inwerk en spanning meebring (bl 85). So roep Paulus (en ons!) uit: 'Ek, ellendige mens, wie sal my verlos?'

So het Swanepoel met slegs enkele opmerkings oor die ses standpunte (wat elkeen 'n lang geskiedenis en groot name as voorstanders het) voortgegaan om sy eie standpunt na aanleiding van 'n kombinasie van standpunte 1 en 2 (wat eintlik in 
wese dieselfde is) te gee.

Daar kan volstaan word met hierdie paar kritiese opmerkings, want dit is genoegsaam om te konstateer dat hierdie bydrae nie oortuigend is nie. Die rede is dat die outeur metodologies te ongenuanseerd (somtyds naief) te werk gaan en in sy eksegese te maklik kort pad kies sonder om werklik in diepte in gesprek met teoloë en bestaande standpunte te tree. Daar is ook geen finale konklusie aan die einde van die artikel nie.

Enkele ander punte van kritiek is die volgende:

- Dit is onaanvaarbaar dat die Literatuurlys agt titels bevat waarna nèrens verwys word nie (soos Bauer, W 1973; Belleville, L L 1986; Brannick, V P 1985; Brauch, M T 1975; Louw, J P \& Nida, E 1988; Murray, J 1970; Schmithals, W 1980; Wedderburn, A J M 1985).

Op bladsy 84 word weer na 'n hele aantal outeurs verwys (o a na Calvyn wat nie in die Literatuurlys voorkom nie) sonder verdere aanduiding van jaartalle en bladsyverwysings.

- Die naam van die tydskrif Journal of the Study of the New Testament moet afgekort word tot $J S N T$ en $C B Q$ moet ook in kursiewe vetdruk verskyn.

- 'n Baie groot tekortkoming en punt van gewigtige kritiek teen die artikel is dat, behalwe Louw \& Nida (waarna nie eens verwys word nie), géén publikasie en standpunt van enige Suid-Afrikaanse teoloog aandag kry nie. En dit geskied terwyl die Sitz im Leben van hierdie bundel opstelle juis die Suid-Afrikaanse is! Swanepoel kon in die beskikbare Suid-Afrikaanse Teologiese Bibliografie van die Instituut vir Teologiese Navorsing aan UNISA (1980, 1983, 1988 en 1989) al die bydraes oor die Romeinebrief opgespoor het.

In die bydrae van $J G$ du Plessis oor 'Romeine 9-11: Die snykant van genade' word hierdie gedeelte as 'n argumentatiewe teks vir die oorreding van die lesers vanuit 'n literêr-kritiese perspektief bekyk. Hierin word op bekwame wyse aandag aan die kommunikasie-situasie, die spreker (Paulus) en sy gespreksgenote gegee. Eintlik het Du Plessis in sy analise hoofsaaklik aandag geskenk aan die konteks en werkwyse van die outeur en is die vraag na die suksesvolheid van sy argumentasie gevra. Hy beklemtoon ook die feit dat hierdie Pauliniese argumentasie die teenswoordige leser voor die appél van God se genadige barmhartigheid plaas.

Hierdie is ' $n$ waardevolle bydrae waarin die teologiese verwysingsraamwerk en konteks van die destydse outeur en 'n deel van sy lesers skerp onder die soeklig geplaas word. Die slotsom waartoe deur 'n sistematiese analise gekom word, ontsluit hierdie gedeelte vir verdere besinning oor hoe die Nuwe Testament op enige 
leser daarvan appelleer wat soos die destydse Jode lesersweerstande het in die vorm van tradisionele teologieë.

Die feit dat Du Plessis slegs vier titels in sy bronnelys aangee (drie kommentare en een monografie), beteken dat hy oor 'n baie eng front met ander geleerdes in gesprek tree en dus eintlik sy eie besinning en analise op die tafel wil plaas. Vir oorspronklike werk is daar natuurlik in Suid-Afrika baie ruimte en groot behoefte.

$C J A$ Vos se bydrae gaan eweneens oor die kwessie van uitverkiesing, juis na aanleiding van Romeine 9-11. Teenoor Du Plessis se bydrae bied Vos s'n 'n perspektief vanuit die sistematiese teologie en dogmengeskiedenis.

$\mathrm{Na}$ aanleiding van insigte verkry uit Newton se kwantumfisika beskryf hy uitverkiesing as 'n bipolêre aangeleentheid, bestaande uit God se vrymag èn die verantwoordelikheid van die mens en bewoord hy die titel van sy opstel gepas as 'Uitverkiesing: God en/of mens?'

Die ondersoek bied 'n dogmenhistoriese oorsig ('n tipe van 'n geskiedenis van navorsing) waarin Reformatoriese denke, díe van die Pelagiane en Semi-Pelagiane, Arminiane, ensovoorts, krities oorskou word. Hierin behandel Vos klassieke dilemmas in die dogmengeskiedenis, soos verkiesing' en sy komplement 'verwerping' (kyk Rom 10:1v). Sy beredenering en formulering berus op, onder andere, die Dordtse Leerreëls, Calvyn, Berkhouwer en eksegete soos H N Ridderbos, E Käsemann saam met O Michel en J P Louw.

Hy konkludeer dat Romeine 9-11 eindig met 'n loflied van 'n 'oop slot' wat sê dat God se genade die menslik onmoontlike moontlik maak (kyk bl 118).

Vos se bydrae is 'n waardevolle oorsig van hoe 'n sistematiese teoloog konstrukte met betrekking tot die uitverkiesing en aanverwante sake ontwerp.

Wat sistematiese teologie betref, staan sy analises en sinteses so sterk soos wat dit seker kan en is dit waarskynlik ook verteenwoordigend van die stand van sake in Switserse (Calvyn se werke verskyn nie in die Literatuurlys nie), Duitse, Nederlandse, Engelse en Suid-Afrikaanse geledere, soos gereflekteer vanaf 1952 tot 1988.

Wat eksegetiese arbeid op hierdie terrein betref, word gebruik gemaak van sy eie poging saam met díe van Käsemann, Michel, Pesch en Ridderbos. Hierdie paar groot name kan egter nooit as verteenwoordigend beskou word van die besinning oor Romeine 9-11 wat so problematies is en waaroor al so baie geskryf is nie. In die lig van die feit dat die oorspronklike lesings en hierdie hele bundel opstelle bedoel was en is om oor sulke 'probleemgevalle' in die Romeinebrief te herbesin, moet gevra word: As die eksegetiese ondersoek van Romeine 9-11 'n wyer en baie meer verteenwoordigende spektrum gedek het, sou die bydrae nie groter en die argumente nie beter gesubstansieerd gewees het nie? Sou die besinning van siste- 
matiese teoloë (soos Vos) nie ook sóveel gebaat het by hierdie wyere herbesinning en dus verdere onafhanklike ondersoek, dat ons in 1990 'n hele ent verder op ons soeke na die waarheid oor uitverkiesing sou wees nie - veral aangesien dít juis die intensie van hierdie bundel lesings was? Die antwoord op hierdie vrae is natuurlik: Ja, beslis! Hierdie antwoord skaal die waarde van hierdie bydrae af tot op die vlak van 'n standaardgraad kompilasie, wat wel enige verduidelikende kommentaar en waardevolle kritiese kanttekeninge by sekere aspekte van tradisionele standpunte oplewer.

$C$ du Toit, 'n sistematiese teoloog, skenk aandag aan etiese dimensies in Romeine 12-16, soos liefde as beginsel vir alle handelinge en die kwessie van die swakkes en die sterkes (14-15). Hy gee 'n waardevolle beskrywing van die agtergrond van die Romeinebrief, asook van die teologiese en godsdienstige denkwêreld van die geadresseerdes van die brief (kyk bl 128, 132vv). Binne sy hermeneutiese model ag hy tereg hierdie inligting as van belang en hy maak 'n keuse vir 'n bepaalde beskouing hieroor wat redelik verteenwoordigend van die kern van huidige opvattings is.

Die uiteensetting oor die sogenaamde swakkes en sterkes (kyk bl 128-131) gaan oor Romeine 14:1-15:13 en word aan die hand van vier aspekte in vier perikope analities en sistematies aangebied. Die tekortkoming hier is dat Du Toit hier slegs met twee (U Wilckens en D A Black) van die dertien teoloë van sy Literatuurlys in gesprek tree, so asof hierdie twee (saam met homself) die hele spektrum van beskouings en die volle omvang van die waarheid dek!

'n Ander goeie bydrae in hierdie afdeling is sy sintese wat geformuleer word as Paulus se 'teologie van swakheid', oftewel, 'skat-in-erdekruike-teologie' (kyk p 131).

Enkele kritiese opmerkings oor die bydrae is egter nodig.

- Die groot tekortkoming van die artikel is dat Du Toit, strydig met sy spelreëls as 'n sistematiese teoloog, nie aan die einde die bevindinge van sy analise in 'n sistematiese konklusie weergegee het nie, terwyl hy dit wel ten opsigte van Romeine 14:1-15:13 gedoen het.

- Die gevolg van hierdie tekortkoming is dat die leser(es), wanneer hy/sy die artikel klaar gelees het, ongelukkig nie 'n duidelike beeld van die 'etiese dimensies van Romeine 12-16' het nie.

* In die eksegese is te swaar en eensydiglik op Wilckens gesteun - 50\% van al die verwysings is na hierdie outeur. Die artikel van G H Ter Schegget, wat direk oor dieselfde onderwerp handel, word slegs eenmaal verwys. 
* In laasgenoemde verband geld ook die kritiek dat P J Achtemeier en J van Bruggen in die Literatuurlys vermeld word, maar nie na hulle verwys word nie. Verder, wanneer na meer as een outeur tesame verwys word (soos op bl 120, $125,132)$, moet hulle of kronologies of alfabeties gerangskik word.

* Dit is nie aanvaarbaar om te verwys na outeurs (soos na C H Dodd, R Bultmann en E Käsemann - bl 124), maar nie datums van titels te verstrek en ook nie die titels in die Literatuurlys op te neem nie.

E van Niekerk se bydrae gaan oor die Christen en die staat (kyk bl 137-54), met spesiale verwysing na Romeine 13.

Soos so kenmerkend van Van Niekerk, 'n sistematiese teoloog met 'n sterk wysgerige onderbou, gee hy 'n verhelderende en kritiese analise van frases soos 'die Christen en die staat', 'burger en staat', waarin hy die afsonderlike komponente van hierdie frases en hulle verband tot mekaar en assosiasie met mekaar onder die loep neem.

Hierdie artikel lewer ook 'n waardevolle bydrae tot die vra van noodsaaklike hermeneutiese vrae oor die manier waarop die Bybel gebruik word in die nadenke/ spreke in die algemeen en oor die staat en die samelewingsbeskouing wat hermeneuties hierin funksioneer. Hy konstateer dat Christene gewoonlik 'n bepaalde hermeneutiese paradigma oor die Bybel daarop nahou na aanleiding van wat hulle as die omvattende tendens of skopus (my kursivering) van die Bybel beskou.

Ter substansiëring van sy hermeneutiese aksioom van die dominante rol wat 'n bepaalde samelewingsbeskouing in die verstaan en uitleg en interpretasie van die Bybel speel, gaan Van Niekerk terug na Romeine 13. Ook hier word 'n bepaalde samelewingsbeskouing, respektiewelik staatsfilosofie en -bestel geprojekteer, te wete nie 'n demokratiese regstaat soos in die Weste en die RSA nie, maar 'n Romeinse magstaat waarin die owerheid sinoniem gestel word met die staat. Die belangrike implikasies hiervan vir die verstaan en uitleg van Romeine 13 is dat Paulus hier beslis nie demokratiese regstaat-beginsels (soos openbare vryheid van spraak, asook meningsvryheid, stemreg, reg tot kritiek op die staat, ensovoorts) aanspreek nie (kyk bl 140).

Hiermee spel Van Niekerk, in aansluiting by D F M Strauss (1988), 'n ander belangrike aanname in sy hermeneuse uit, naamlik dat die Bybel en Paulus nie struktuurbeginsels van die staat en kerk daarstel nie. In die Bybel funksioneer slegs verskillende staats- en kerkbeskouings wat gebonde was aan heersende kontemporêre samelewingsbeskouings.

In 'n belangrike paragraaf van sy artikel (kyk bl 141-48) gee Van Niekerk, in aansluiting by L Pohle (1984), 'n waardevolle oorsig van vier interpretasiemodelle 
van Romeine 13. Sy kritiese bespreking van hierdie modelle wys uit dat elkeen hiervan berus op 'n bepaalde teologiese persepsie en dat hulle op grond hiervan uitgebou word. Hierdie oorkoepelende teologiese persepsies funksioneer as hermeneutiese presupposisies/vertrekpunte wat oor Romeine 13 heen gelees word. Tereg word die derde model, die sogenaamde konkreet-charismatiese model (o a by Käsemann), as meer genuanseerde model uitgesonder van hierdie oorspanning van Romeine 13. Hier word Romeine 13 nie gesien as 'n algemeen-geldige riglyn vir die staatstruktuur nie, maar as spesiale aanwysing ten opsigte van 'n gegewe historiese situasie en as beklemtoning van die regte verhouding tussen die Christen en die wêreld. Teenoor 6бr-entoesiasme by Käsemann (en miskien by Van Niekerk?) oor hierdie model, moet dit egter onthou word dat hierdie model uiteindelik ook werk met algemene persepsies soos 'n eskatologiese grondtema van die Romeinebrief, asook dat charismatiese handelinge in (vanaf?) Romeine 12:3-6 ter sprake is. Volgens hierdie verstaansmodel bevat Romeine 13 geen algemene maatstawwe en norme vir Christene se optrede teenoor die staat nie, maar wel norme vir charismatiese diens aan God.

Die waarde van hierdie model is dat die aksent gele word op individuele funksionarisse van die staat en hulle persoonlike verhouding tot burgers(esse) van die staat, en nie op die staat as instelling nie. Wat die Christen betref, staan hy/sy in 'n charismatiese handeling van diens teenoor hierdie funksionarisse en die staat.

Van Niekerk voeg 'n vyfde model hier by, naamlik die sosiale kontrak-model waarvolgens die Bybel direk van toepassing op die kerk, maar nie op die staat is nie. Ten opsigte van laasgenoemde moet Christene hulle gesonde verstand gebruik en daarvan kennis neem dat mense - ook Christene - hulle regte en vryhede deur middel van sosiale kontrak ingekort het deur aan sekere ander mense opdrag te gee om oor hulle te regeer.

Van Niekerk som sy nadenke hieroor op deur op twee geldige punte te wys, naamlik:

* Die vyf modelle gaan om 'n antwoord op die vraag: Gee Paulus in Romeine 13 'n kort begrip en wegwysende analise van die struktuur van die staat soos geldig vir alle tye; of gaan dit om algemene raad vir mense in Rome in die eerste eeu èn ook vir ons in ons tyd oor wat behoort gedoen te word terwyl ons in die lewensverband van die staat in diens van God wil wees?

* Verskeie voorafingenome standpunte/vertrekpunte/teologiese persepsies konstitueer en bepaal hierdie vyf modelle en níe die eksegese van Romeine 13 nie. In 'n kritiese evaluering van die modelle kom Van Niekerk tot die slotsom dat inlegkunde dus op groot skaal gepleeg is. Immers, 'n struktuuranalise van die staat kan nie uit die Bybel en Romeine 13 afgelei word nie. Veeleer moet ons in 
ons samelewingsverband, waarvan die Bybel deel is en reeds 'n rol speel, die staat analiseer. In hierdie analise moet die omvattende tendens/skopus van die hele Bybel as norm 'n regulerende rol speel. Tot 'n sekere mate gebeur dit ook by die vyf modelle. Wat metodologies egter moet gebeur - en nie in die vyf modelle gebeur nie - is dat ten opsigte van die skopus die proses van die hermeneutiese spiraal noodsaaklikerwys altyd uitgevoer moet word.

Ten slotte poneer Van Niekerk sy eie konsep van so'n skopus. Dit omvat drie komponente, naamlik:

- God as skepper relativeer alles tot hulle eie aard en niks is absoluut nie.

- Heil/welsyn in die wêreld word vergestalt in sin, met as teenpool on-sin, kwaad; ook in bevryding en versoening ( $\mathrm{d} i$ een-met-ander-te-wees). Die kruis en opstanding van Jesus is die sinvolle en bevrydende impulse vir heil/welsyn van die mens in 'n goeie aardse lewe.

- Op weg na 'n nuwe mens en 'n nuwe wêreld van môre is mens en wêreld aan verandering en vernuwing onderworpe. So beskou, bestaan Van Niekerk se grondskema vir die verstaan en lees van enige gedeelte van die Bybel uit drie komponente, naamlik, vrae na die oorsprong van alles, na die heil/welsyn van alles en na die vernuwing van alles.

Toegepas op Romeine 13 beteken alles wat gesê is, dat Paulus hier dink in terme en binne die raamwerk van 'n magstaat van Rome en die se verhouding tot en magsgreep op die onderdane. Hy ken nie die moderne demokratiese regstaat nie. Owerheid en staat is vir hom sinoniem - soos dit by ons ook funksioneer.

Hierdie persepsie lei gewoonlik tot oorskryding van die perke van gesagsuitoefening deur die staat en tot konflik van die onderdaan tot die owerheid/staat.

In 'n demokratiese regstaat, wat glad nie in Romeine 13 ter sprake is nie, behoort dit te gaan om regsmag van die onderdane waarin geregtigheid en billikheid moet seëvier. Die staat bestaan uit regering èn burgers en nie net regering nie. Die regering het 'n taak, roeping en funksie terwyl al die reghebbendes en regsbelange inspraak het in wat hierdie taak, roeping en rol is/behoort te wees.

Hierdie bydrae van Van Niekerk getuig van goeie huiswerk wat met die oog op herbesinning gedoen is. Die wysgeer en sistematiese teoloog is op 'n deurdringende wyse hier aan die woord. Wat hy te sê gehad het, kom duidelik by die leser uit om dit te beoordeel. Hiervoor word groot waardering betuig.

Die volgende kritiese vrae moet egter gevra word:

- Hy lê Skrifuitleggers en teoloë en selfs vir Paulus dit ten laste dat hulle met 'n 
vooringenome persepsie en samelewingsbeskouing die Bybel en vroegChristelike tradisies verstaan en uitlè, en dus ook Romeine 13 so geskep het (Paulus) en hierdie dinge oor die Bybel en Romeinebrief heen gelees het. Metodologies het hy met sy hermeneuse van die rol van 'n skopus van die Bybel en die effek van die anderssoortige samelewingsbeskouing in Romeine 13, presies dieselfde gedoen. Hoe werk dit?

- Paulus se samelewingsbeskouing en sy feitelike gesitueerdheid binne die wêreld van die Romeinse magstaat word as verwysingsraamwark van Romeine 13 gesien. Dit is waarskynlik hermeneuties en histories korrek om dit so te sien. Die vraag is egter of dit geldig is om hierdie entiteite vanuit ' $n$ ander skaal van samelewingsbeskouing, die demokratiese regstaat, te beoordeel en dit dan as 'n ander benadering tot Romeine 13 en 'n beter eksegese hiervan aan te bied? (kyk hiervoor bl 151v)

- Waar en hoe pas Van Niekerk sy drie-voudige konsep van die skopus van die Bybel toe in sy verstaan en uitleg van Romeine 13 ? Al wat in sy artikel aan die einde daarvan uitgespel word, is die implikasies van sy eie staatsfilosofie, respektiewelik samelewingsbeskouing, wat as opdrag aan regering en burger deurgegee word.

Hy verskuif die fokuspunt en kern van die hele aangeleentheid vanaf die gesag van God wat sonder meer op die staat (en kerk) oorgedra word (soos by Paulus) na die wyse waarop die staat/mense gestalte aan hierdie gesag gee. Dit is baie sinvol om dit so te sien. Maar as gevolg van sy eie siening van die samelewingsbeskouing en konkrete situasie waarin Paulus die Romeinebrief en Romeine 13 geskryf het, word Romeine 13 eintlik op 'n syspoor gerangeer as synde onvanpas as riglyn om die staat en regering en díe se verhouding tot burgers - en omgekeerd - te beskryf. Die rede is dat hy hier 'n ander samelewingsbeskouing sien funksioneer. Hy bly in gebreke om sy drievoudige konsep van skopus as oorkoepelende verklaringsprinsipe vir Romeine 13 en vir ander relevante Bybelgedeeltes oor hierdie aangeleentheid te laat funksioneer.

* Hoe en waar het hy die proses van die hermeneutiese spiraal ten opsigte van sy hermeneutiese presupposisies/vertrekpunte (o a van die omvattende tendens/ skopus) laat plaasvind?

\section{ALGEMENE KONKLUSIE}

Oor die geheel kan van hierdie bundel opstelle die volgende gesê word:

* Dit was 'n lofwaardige gedagte van die Powell Bybelsentrum om teen die einde 
van die voorlaaste dekade van ons eeu in ons eie situasie 'n verskeidenheid Suid-Afrikaanse teoloë na die Romeinebrief te laat kyk.

* Soos hierbo in die waarderende maar ook kritiese oorsig oor die bydraes aangedui, wissel die gewigtigheid van die bydraes nogal aansienlik. Sommiges is kompilatories van aard waarin of tradisionele standpunte herbevestig is, of 'nuwe orde/alternatiewe teologie' weer eens op die tafel gesit is. Ander bydraes getuig nie net van besinning oor metodologie en verantwoording oor die keuse, trefkrag en toepassing van paradigmas van verstaan nie, maar ook van oor-spronklikheid in nadenke, arbeid en resultate.

- Aan die einde van die dag kan en moet gesê word dat vordering wél gemaak is met die proses van herbesinning oor die Romeinebrief as belangrike dokument/bron vir teologie. Maar die leemtes en oneffenhede wat deur die kritiese kanttekeninge uitgewys is, bevestig dat die taak van nadenke en navorsing ver van afgehandel is.

Wat in die besonder op ons studeertafels, agendas vir simposia en persoonlike gesprekke ter sake is, is wederkerige bewustheid van die trefkrag en beperkinge van die verklaringsmodelle wat elkeen aanwend om die Bybel te verstaan en te interpreteer. So'n besef van die relatiwiteit en dus relatiewe waarde van ons paradigmas en ons resultate sal ons baie meer beskeie oor ons eie standpunte maak. Dit behoort ons in ons onderlinge gesprekke en verdere nadenke meer tolerant en oper na mekaar toe te maak.

* Dit is duidelik dat die meeste van ons Suid-Afrikaanse teoloë nog steeds ly aan die kwaal van miskenning van ons eie teologiese bydraes. Miskien is dit 'n besondere soort sindroom wat manifesteer in die vorm van 'n illusionêre bewondering van wat buitelanders gedoen het en nog steeds doen! Hierdie onsmaaklike en onaanvaarbare toedrag van sake word bevestig deur die statistieke verkry uit die artikels in hierdie bundel, wat soos volg daar uitsien en vir sigself spreek:

Die Literatuurlyste bevat 'n totaal van 154 titels.

Hiervan is 139 , dit wil sê $90,3 \%$ buitelandse publikasies.

Met ander woorde slegs 15, dws 9,3\% is publikasies van Suid-Afrikaanse teoloë!

Drie bydraes verwys hoegenaamd nie na werk uit eie bodem nie.

By drie van die elf bydraes is die persentasie Suid-Afrikaanse titels $2,6 \%$, $4,7 \%$ en $11 \%$.

By net een bydrae is hierdie persentasie so hoog soos $43 \%$.

Hierby kom nog dat twee bydraes titels van Suid-Afrikaanse werke in hulle 
Literatuurlyste opgeneem het, maar nèrens daarna verwys het nie.

Hierdie beskuldigende statistieke 'laat 'n mens dink, né!' Dit behoort ons tot nadenke te stem, te meer aangesien hierdie bundel opstelle bedoel was en is om in 1988 in Suid-Afrika te herbesin oor die Romeinebrief, onder andere deur te kyk na wat die geskiedenis van navorsing en die stand van sake hieroor is. Sekerlik sou 'n speurtog deur die vier uitgawes van Suid-Afrikaanse Teologiese Bibliografie van die Instituut vir Teologiese Navorsing, UNISA (1980, 1983, 1988 en 1989) uitgewys het hoevél daar inderdaad in Suid-Afrika al oor die Romeinebrief gepubliseer is. Hierdie feit en verskynsel maak dat verreweg die meeste van die bydraes ongelukkig mank gaan aan onvolledigheid weens die feit dat die in-gesprek-gaan in die proses van herbesinning nie verteenwoordigend genoeg was nie.

As dit alles gesê is, wil en kan ek hierdie publikasie van harte vir lees en bestudering aanbeveel en onder die aandag bring met die oog op verdere herbesinning oor die Romeinebrief as juweel in die Nuwe Testament. Deur hierdie aanbeveling wil ek my waardering betuig vir die werk wat kollegas in Suid-Afrika gedoen het, én wil ook meewerk aan die genesing van die bogenoemde akademiese sindroom. 